\title{
THE STATE OF THE NURSING SCIENCE IN SPAIN
}

Puig RC. The state of the nursing science in Spain. Rev Latino-am Enfermagem 2002 março-abril; 10(2):214-20.

This article is giving a historical perspective of the nursing science in Spain, comparing it with the situation of the science, and nursing science at international level. The author gave a very clear description of the state of the art, and the nursing outcome shared by Spanish authors with the rest of nursing scientific community, arriving to the conclusion that Spanish nursing is at the beginning of a process where, negative factors can be clearly identified and, potential measures to improve relatively easily nursing science can be taken in the short term.

DESCRIPTORS: nursing, research, knowledge

\section{O ESTADO DA CIÊNCIA DA ENFERMAGEM NA ESPANHA}

Este artigo proporciona uma perspectiva histórica da ciência da enfermagem na Espanha, comparando-a com a ciência da enfermagem em âmbito internacional e com a ciência em geral. 0 autor descreve a situação e a produção de enfermagem compartilhada por autores espanhóis com toda a comunidade científica, concluindo que a enfermagem espanhola se encontra no começo de um processo no qual fatores negativos podem ser claramente identificados. Todavia, medidas para facilitar o avanço da ciência de enfermagem podem ser tomadas a curtoprazo.

DESCRITORES: enfermagem, pesquisa, conhecimento

\section{EL ESTADO DE LA CIENCIA DE ENFERMERÍA EN ESPAÑA}

Este articulo proporciona una perspectiva histórica de la ciencia enfermera en España, comparándola con la situación de la ciencia de enfermería en el ámbito internacional y con la de la ciencia en general. El autor proporciona una clara descripción de la situación y de la producción de enfermería compartida por los autores españoles con el resto de la comunidad científica enfermera, llegando a la conclusión de que, la enfermería Española se encuentra al comienzo de un proceso en cual, los factores negativos pueden claramente ser identificados y, las medidas que en potencia pueden fácilmente mejorar la ciencia de enfermería pueden ser tomadas a corto plazo.

DESCRIPTORES: enfermería, pesquisa, conocimiento

\footnotetext{
${ }^{1}$ University of Valencia - Spain, e-mail: ramon.camano@uv.es
} 
In the $19^{\text {th }}$ and early $20^{\text {th }}$ century, nursing practice acquired legal status in Spain, and the profession was institutionalised under three denominations: 'practicante', midwifery and nursing. 'Practicantes' and midwifery were regulated by a Royal Decree of $4^{\text {th }}$ June 1857, and nurses in a Royal Order of $15^{\text {th }}$ May 1915. Training was planned and certain regulations were established for everyday practice with an importance given to subordination and service to another health profession. In 1953 the three professions became one, Ayudante Técnico Sanitario (ATS), which remained until 1977, when the name was changed and nursing became a university degree, thus obtaining autonomy and changing the focus of the professional activities from another health profession to the health of human beings.

From the beginning 'practicantes', midwives and nurses initiated some kind of political actions in order to obtain some benefits from the Spanish government. One of the expected benefits was the acknowledgement of the different professions by the state, and the sanction of it with the issue of state regulations, creating professional colleges. The professional colleges of the Spanish State -including nursing colleges- are organisations of public law and participate in the guard and administrative control of basic rights. In the case of nursing, the rights involved are health care and the right to health. This fact provides them with independence and operativeness.

Given their legal/public nature, colleges carry out some functions related to the professional discipline, deontological rules, criminal and/or administrative sanctions, and appeals, which could not be carried out neither by legal/private associations nor by political parties. They act as consulting organs which manage different issues: technical planning of an overall sector in terms of functions, capabilities, resources, salaries, and working shifts. Ultimately, the collective benefits from such actions are not for the college or the administration, due to public service and general interest of the professional mission of their members.

One of the most reiterated objectives and priorities, since the establishment of the Associations and Colleges of 'Practicantes', Midwifes and later Nurses, in Spain, is to have their own forums and especially the means of publication of their own research, such as journals, bulletins, etc. This objective is recorded both directly and indirectly in the successive regulations that gave way to the creation of the professional colleges; this is the chronological order: Item $i$ article 5 sets the aim of the Colleges in the Orders of 1929 and $1930^{(1-}$ 2): the colleges must develop all the charitable and cultural aims foreseen in their particular regulations (one of those cultural aims was the publication of journals).

In the same Orders, article 13 established, as a duty, that the secretary of each college registered all the members in full detail; a list would then be passed on to the Directorate General for Health, Provincial Health Inspection, and Medical Sub-delegations every year, and any amendments to the list would have to be published in the institution's Official Bulletin. The Bulletin was the communication organ of the colleges (obviously for those who had it), and included all the aspects previously mentioned as well as those relative to scientific communication.

The Order of 8 March $1941^{(3)}$ (article 1) established that until new statutes were approved, colleges had to continue operating in accordance with the statutes passed by Order 22 December 1929 as to all the areas which had not been modified by other regulations or by the Order. The publication of the college bulletins was so ensured.

Item $g$ in article 4 of the same Order established as the exclusive function of the General Council of the Official College of 'practicantes' the publication of a bulletin including scientific, professional and legal works of interest for 'practicantes'.

Later on, an Order dated 18 March $1942^{(4)}$ (item j, article 5, Chapter 5) described the following college roles: promote and develop charity work, cultural activities, etc., that may be of interest to the Class* (this reminds us of previous regulations). Article 23 stated that the agreements reached by the colleges had to be published in the Official Bulletin of the Council if they contained references to general measures affecting the Class. This duty had been exclusively assigned to the General Council and was again reiterated by the Order dated 26 November $1945^{(5)}$. In article 3 , the function was established to be exclusive to the Council: the Council was to publish a bulletin including scientific, professional and legal works of interest to the Class, and to which all Spanish health auxiliaries registered with a college had to subscribe.

The Order of 21 June $1951^{(6)}$ established the Statutes and Regulations of the Midwifery Colleges. Item 6 in article 6, Chapter I, describes all those scientific and cultural aims which would be found relevant. In the same regulation, Article 12 in Chapter II established that the secretary of the Managing Board of each college had to keep records of the midwives registered, which would be annually submitted to the college members, the provincial Health inspectors, the General Council, and the Directorate General for Health. The amendments if any-were to be published in the Official Bulletin on a monthly basis. This communication organ was therefore used both as a registry and for tax purposes, and also as a way to circulate knowledge amongst the members.

Item $h$ in article 6 of the Regulation of the National Council of Health Auxiliaries, developed by the Order of 29 March $1954^{(7)}$,

\footnotetext{
${ }^{*}$ At that time, the Spanish generic name of all the health professions was 'Clases Sanitarias' which included different professional health groups: doctors, 'practicantes', midwives, aphotecaries, etc.

'Practicantes' used to enjoy this name
} 
established a task which is exclusive to the National Council, that is, the publication of a Bulletin containing as many official news and reports of interest to the professionals. The Bulletin had to be distributed to all the college members. In addition to the bulletin, each of the sections -individually or in joint schemes with the other sectionscould publish a journal with scientific, literary, and socio-professional contents, of interest to the group.

Item 0 , in the same article, states that -under the direction of the Health Authorities and the Medical Body-the study will promote initiatives for the improvement of public health and care techniques, and will stimulate personal efforts.

This norm also included an appendix with a Moral Code establishing certain moral duties for health auxiliaries (article 3): the professionals should be aware of their responsibilities, and always try to increase their knowledge, keeping up-to-date in science. Neither the appendix nor the regulation articles refer to independence from doctors; auxiliaries are encouraged to update their educational activities but not their research.

In 1973, the Spanish college organisation joined in the nursing code of the International Nursing Council ${ }^{(8)}$. The section 'The nurse and the profession' reads: "nurses should actively contribute to the development of nursing knowledge". The only way to add to an active contribution and development is research. The observance of the code meant a quality change which would later bring in irreversible changes as to professional autonomy and research, as it implied the recognition of nursing research as something different from past activities, even in the opinion of the nurses themselves, something worth working on. This would eventually lead to deep transformation; the consideration of nursing by the patients changed dramatically, and the aspirations and demands also evolved in terms of autonomy. Changes are still occurring, especially as far as research is concerned.

In the college regulations, there is no further reference to the development of information means, bulletins, journals, etc., as from this moment the highly important college function of distribution of scientific, literary and socio-professional materials is taken for granted. Therefore, all those colleges that have funds available do publish journals or bulletins.

In the Deontological Code of Spanish Nursing ${ }^{(9)}$-published in 1989- we find two articles which represent a commitment to research and professional development; article 70 reads:

The nurse will be aware of the need to be up-to-date by means of staff development schemes and through the development of the knowledge on which his/her professional practice is founded,

and article 73 reads:

The nurse must try to research systematically in the field of his/her professional activity, aiming at improving the nursing care, discarding incorrect practices, and extending the scope of his/her knowledge.
Both articles implicitly promote the creation of journals for publishing the results of research, as any progress that is not circulated cannot really be considered progress, since it is not integrated in the corpus of the scientific knowledge of the corresponding professional group, in this case nursing.

All this progress would not have been made without spreading the knowledge generated. Nowadays, the results of scientific activity are spread through different media and systems, especially through written articles in scientific journals and books. Some authors believe that research is not concluded until the results are known by the rest of the scientific community concerned with the subject matter ${ }^{(10-11)}$.

Today, scientific articles constitute one of the most important means of communication among scientists. In nursing, scientific papers have several objectives: firstly, to spread the progress made in the different nursing fields; secondly, to instil in them a didactic nature; thirdly, to expose the research to review by colleagues; and lastly, to permit the review of the results of the previously published research. Other aspects are personal promotion and the professional stimulus received by the authors.

It was described ${ }^{(12)}$ in the 80 's described that daily production of scientific articles were about 6,000 , which means that scientific knowledge doubles every other year. Currently, 10,000 journals of health sciences are published on a yearly basis, with a production of over 600,000 articles per year, without including publications which may have a more or less related content, such as essays on psychology, biology, sociology, anthropology ${ }^{(11)}$.

It was described in $1973^{(13)}$ : The continuous duplication which takes place approximately every 15 years and which has led to the present scientific era, accounts for the peculiar contemporaneity which enables us to affirm that most of the science is current and that most of its generators live today. According to this law, if we state that the number of scientists doubles every 15 years, during such an interval there would be as many new scientists as there have been during all previous eras. But the scientists who coexist in a certain period are not only those who have appeared in the last 15 years; they have appeared over a period of 45 years, between the age at which a person would start researching and retirement age. Therefore, for each person born before the 45 year period, there is one born in the first duplication period, two in the second, and four in the third.

This law seems to apply in the work ${ }^{(14)}$ : starting with $\mathrm{H}$. Peuplau, the author establishes a chronology of nursing authors (she stresses how she has used the theoretical concept in nursing, including in her list those contributions which have been recognised in her country of origin). The list is not exhaustive, but it is sufficiently expressive: in the first 15 years (1950-65) and starting with Peplau, we find 8 theoretical contributions; in the following 15 years (19661980 ), we find another 9 , which added up to the previous figure makes 
up 17, and finally for a third period (1981-90), there were 7 , which totals 24. This study should now be repeated in order to include the theorists that have appeared in recent years.

According to the author ${ }^{(14)}$, the concentration of theorists in the USA took place between 1955 and 1980, whereas the first European contributions date back to the late 1970s following the influence of the Americans, which coincides with the chronologies made by different authors concerning the start of theoretical nursing in Europe (there is a chronology for England but not for Spain). Readers may get the impression that this part of the research is about theorists and theory development instead of research in Spain, but theorists are at the forefront of the profession. They stimulate publication, as they must share their ideas by writing papers in journals. They are the catalyst for new research articles and more writing. The growing number of theorists definitely indicates the growth of research in a profession and of the publication of articles.

Therefore, we could consider that what is valid for science in general is also valid for nursing, possibly in a more particular way as far as the nursing process is still at its first stages. It was accorded that: The function of growth and its regularity help us explain the feeling we get that most of the greatest scientists live today and that most of the scientific contributions have been made in the times of the present generation ${ }^{(13)}$.

In general terms, these words were valid for science in the 1970s. In nursing, the greatest contributions will be possibly made in the near future, although it is commonly accepted that numerous theoretical aspects have already started to crystallise. Some of the contributions Maanen refers to are in a paradigmatic situation and in a developing status for the constitution of conceptual frameworks, models and theories. In the authors view ${ }^{(13)}$ : The principle (referring to his previously quoted words) is even more evident if we underline that in the period covered from the next decade to the end of the following one, there will be as many researchers and works as in the total of the previous eras.

The changes which nursing has undergone in Spain in the last two decades, both at an academic and professional level and as to the evolution of the health system, have drawn a favourable framework for the progressive incorporation of nursing professionals in activities of scientific knowledge generation and communication.

We must take into account that at present it is impossible to quantify the totality of the nursing scientific production developed in Spain, as there are no complete data bases of nursing research projects (either finished or under way). In addition, the results of numerous projects are not circulated beyond the area where they first originated. In Spain, the first attempts to define the subjects of nursing research in a generic way -subjects that should be addressed by the whole health system- date back to the early 1990s. Such efforts were first made by Fondo de Investigaciones de la Seguridad Social $(\mathrm{FISS})^{*}$ and then continued by different autonomous governments. The different documents drawn up by the different groups set out strategies and priority lines aimed at fulfilling three important goals: more health, better care, and greater professional development. Such relevant targets have certain aspects that are common to the objectives pursued per example by the National Centre for Nursing Research in the United States ${ }^{(15)}$. Nursing research projects have been passed by FISS since 1988, this allowing nurses to become the main researchers. The projects are assessed by expert panels including nurses.

Table 1 - Evolution of funding applications for nursing research projects in FISS

\begin{tabular}{ccccccc}
\hline Year & $\begin{array}{c}\text { Projects submitted } \\
\text { by nursing }\end{array}$ & $\begin{array}{c}\text { Nursing projects } \\
\text { passed }\end{array}$ & $\%$ passed projects & $\begin{array}{c}\text { Total submitted } \\
\text { projects }\end{array}$ & $\begin{array}{c}\text { Total passed } \\
\text { projects }\end{array}$ & \begin{tabular}{c}
$\%$ passed projects \\
\hline 1989
\end{tabular} \\
7 & 5 & 71,4 & - & - & - \\
1990 & 13 & 10 & 76,9 & 1043 & 734 & 70,37 \\
1992 & 19 & 9 & 47,3 & 940 & 496 & 52,70 \\
1992 & 30 & 13 & 43 & 1252 & 604 & 48,24 \\
1993 & 7 & 7 & 100 & 1021 & 633 & 52,70 \\
1994 & 46 & 13 & 28,2 & 1837 & 712 & 38,75 \\
1995 & 50 & 7 & 14 & 1864 & 530 & 28,43 \\
1996 & 47 & - & - & - & - & - \\
Total & 212 & 59 & 27,00 & 6273 & 3709 & 28,43 \\
\hline
\end{tabular}

The information available only covers up to 1996, when FISS stopped publishing the data

* Office of the Ministry of Health to promote develop and funding research in the Health System 
Other funding institutions are not regarded, such as the Autonomous Communities, the employers, professional associations, foundations... However, in comparison with other fields, FISS funds most of the nursing research, but -as shown by the Table 1 - the funding is insignificant.

A way to get to know the reach of scientific production in nursing and the professional expertise in contributing to the development of the discipline is the study of the papers published in the nursing journals. In other words, the nursing outcome shared by the authors with the rest of the nursing scientific community.

Papers do not make up the totality of the nursing scientific production, but they do show how prepared professionals are in the development of the discipline and its scope, through a tangible result, i.e. written evidence accessible to the rest of the scientific community. In this way, one of the basic demands of scientific knowledge is met.

We shall now proceed to review the emergence of the nursing journals, as their increased number will certainly have positive repercussions on the analysis of the evolution of nursing research. The rise results from the increased demand by the authors, who want to see their papers and research published.
To begin with, journals covered different subjects, their production was mainly national, and their publication general (Revista Rol de Enfermería, Enfermería Científica, Enfermería Clínica, etc.). Later, specialised journals started being published related to professional associations; they were used as a meeting point, a place for the communication and information of those subscribed, their main objective being the consolidation of the speciality and the acquisition of an identity (Enfermería Intensiva, Revista de la Asociación de Enfermería Urológica, etc.).

Journals are published by the Nursing Colleges (Inquietudes profesionales, Salud y Ciencia: Revista Aragonesa de Enfermería, Enfermería Integral, etc.), the General Board of Nursing (Enfermería Actualidad), the Union of Ayudantes Técnicos Sanitarios de España (SATSE) (Mundo Sanitario), hospitals, and the University Schools of Nursing (Revista de la Escuela de Enfermería "La Fe", etc.). All the journals meet the needs of the nursing profession and are included in secondary publications that may be defined as the paradigm of Spanish research through the indexing and analysis of the contents (Index de Enfermería). Only the overall vision allows us to comprehend scientific production and its characteristics.

Table 2 - Year of appearance of some currently published Spanish journals

\begin{tabular}{|c|c|}
\hline Year & Hane \\
\hline $197 \diamond$ & Revista Rol de Enfermería \\
\hline $19 \otimes 0$ & Revista de la Asociación de Enfermería Urológica \\
\hline $19 \otimes 1$ & Inquietudes profesionales \\
\hline 1982 & Enfermería Cientíica \\
\hline 1983 & Nursing \\
\hline $19 \otimes 5$ & Escuela de Enfermería \\
\hline 1985 & Enfermería Integral \\
\hline 1987 & Hygia \\
\hline $19 \otimes 8$ & Enfermería Intensiva \\
\hline 1989 & Salud y Ciencia: Revista Aragonesa de Enfermería \\
\hline 1990 & Revista de Enfermería (U. Albacete) \\
\hline 1990 & Gerokomos \\
\hline 1990 & Revista de la Sociedad Española de Geriatría y Gerontología \\
\hline 1991 & Enfermería Clínica \\
\hline 1992 & Index de Enfermería \\
\hline 1992 & Enfermería Canaria: Rev. de la Federación de Colegios Canarios \\
\hline 1994 & Hiades \\
\hline 1995 & Enfermería Actualidad \\
\hline 1996 & Mundo Sanitario \\
\hline 1998 & Revista de la Escuela de Enfermería "La Fe" \\
\hline 1998 & Metas de Enfermería \\
\hline 1998 & Revista de la Sociedad Española de Nefrologia \\
\hline
\end{tabular}

In Table 2 we will see a constant increment and appearance of new journals in Spain. The list is not exhaustive, but will give an idea of the evolution that will not be stopped, journals than appeared when nursing arrived to university and will have an important development at the moment, that nursing profession in Spain will obtain the nursing doctoral degree.

In order to produce knowledge, one of the most important elements to be developed by the professionals is education. Education must include methodological aspects capable of bringing in research elements. In 1990, was identified ${ }^{(16)}$ that the deficit in the 
methodological training together with the scarce sources are the most serious shortages that nursing has come across, as professional development can only occur when new and varied data are available from different sources.

Research, as it is acknowledged in the nursing curriculum must:

- Be integrated within a global vision, as another component in everyday life, neither detached nor disconnected from the theoretical/ practical contents.

- Promote experiences in students -on an individual basis or as part of a group-; integrate the students into research groups formed by nurses with different levels of expertise and doctors in nursing who would help develop all aspects of research: data collection, methodologies, procedures, assessment techniques, resolution of problems, etc.

- Have quality and be accurate, trying to replicate analyses in order to obtain contrasted basic knowledge, establishing laws through continuous verification, pooling efforts to build up a body of knowledge. This may require to set up international research networks to favour the development of coherent, universal and true foundations.

- Promote information retrieval and use; information must be accessible, and nurses must be able to find the publications relevant to their research, and see whether or not they are any use; that is, nurses must be able to know how and where more knowledge can be found. Access to updated information is essential in research, and therefore it is necessary to use and analyse the information available, ascertaining its current value.

Nevertheless, one must bear in mind that the introduction of this subject into the curriculum is relatively recent, as it was not taught prior to 1978. Consequently, a relevant number of the currently employed nurses, with steady jobs and experience, have not been academically trained on research methodology. Yet, those who have actually been trained in the last two decades, do not often have the opportunity to put their research knowledge into practice.

Articles which include an analysis of scientific production in nursing are quite recent in Spain. The authors' major concern is to describe the main traits of scientific production in nursing, for which several elements were established which were later treated statistically. The elements ranged from the internal structure of the articles (abstract, sub-titles, presentation) to quality, research area, subject of research, instruments, place of research, designs, number of authors, academic qualifications, etc.

If we follow the comments made by the authors, we get an idea about the capacity of nursing professionals to produce scientific knowledge. Was commented ${ }^{(17)}$ on two research projects on the scientific production of Spanish nursing which had not been published at that time (one was to be published later; Icart et al., 1991). In her opinion, both underline that the number of articles published "doubles and even triples from year to year", but a lack of continuity is observed in the works as well as a lack of recommendations for subsequent work on the subject.

Since 1990, articles have been successively produced which analyse the capacity of professionals to contribute to the development of the discipline ${ }^{(11,18-19)}$. Some of them analyse a specific segment of production, such some authors ${ }^{(20)}$, who focus on scientific production in primary care ${ }^{(21)}$, who analyse the scientific nursing production in oncology.

In the other paper ${ }^{(22)}$ has a slightly different content but it is in the same line. He analyses the literature references used by the authors in the research papers published over a two-year period in three Spanish journals. The author notices that the use of specific and recent bibliography is somehow lower in the Spanish scientific nursing literature than in journals like Nursing Research (American) and Journal of Advanced Nursing (British) in 1990; however, he mentions that there is an increasing development at the moment.

Possibly, one of the elements that have made scientific production dynamic in Spain following the incorporation of nursing in universities in 1978 is the link between the scientific production by university-associated professionals and the allocation of more resources and larger budgets by the Administration. The resources are in turn related to the quality of research.

This situation is not new, in England for e.g. where -since 1986- the quality of research in the different university departments, including nursing, is analysed. It was analysed ${ }^{(23)}$ the results obtained by the University Financing Council in Research Assessment Exercise. This consisted of a survey in which 29 departments were assessed, with a 1 (none or virtually no excellence sub-area) to 5 scale (some international excellence area or different national sub-areas); 19 departments were rated as 1; others received a 2; 2 departments scored 3 ; and, finally, only 3 departments got a 4 . None of the nursing departments attained grade 5 .

This author describes that those departments in the oldest universities -which at the same time are the oldest departmentshave a higher number of researchers and got the best rates in the survey. The lower rates corresponded to departments in newer universities which originated from the disappearance of the binary system of Universities and Polytechnics in England, many of which were more concerned with academic and educational matters than with research and had a reduced staff, which seems to have caused the low rates obtained in the assessment.

These ideas are supported by the other author ${ }^{(24)}$ who describes what he calls the "uniqueness of nursing" as a combination of factors: they range from difficulties in finding funds and time, to 
lack of experience, a large number of new institutions and a low practical level. Smith considers that each of these factors is not relevant in itself, but when combined, result in low quality levels in nursing research. In addition, he compares several nursing journals (a new journal, and two with several decades of experience) to a medical journal, and concludes that nursing should not be afraid of being compared to medicine. There are specific areas where nursing must develop but medicine can also learn from nursing. In the author's

\section{REFERENCES}

1. Ministerio Gobernación (ES). Real Orden de 22 de Diciembre. Estatutos para los Colegios Oficiales Practicantes en Medicina y Cirugía. España; 1929.

2. Ministerio Gobernación. Real Orden de 7 de Mayo. Matronas. Estatuto para los Colegios. España; 1930.

3. Ministerio Gobernación (ES). Orden de 18 de Marzo. Practicantes. Normas para funcionamiento de los colegios. España; 1941.

4. Ministerio Gobernación (ES). Orden de 18 de Marzo. Practicantes y Matronas. Estatutos de los Colegios Oficiales de Practicantes. España; 1942.

5. Ministerio de la Gobernación (ES). Orden de 26 de Noviembre. Sanidad. Aprueba: Reglamento y Estatutos del Consejo General de Auxiliares y de los Colegios Provinciales Respectivamente y los Estatutos del Consejo de Provisión y Socorros Mutuos. España; 1945. 6. Ministerio Gobernación (ES). Orden de 21 de Junio. Colegios de Matronas. Estatutos y Reglamento. España; 1951

7. Ministerio de la Gobernación (ES). Orden de 29 de Marzo. Consejo Nacional de Auxiliares Sanitarios. Reglamento. España; 1954.

8. Consejo Internacional de Enfermería. Código para Enfermeras. Ginebra: CIE; 1973.

9. Consejo General de Diplomados en Enfermería. Código Deontológico. Madrid: Consejo General de Diplomados en Enfermería; 1989

10. Amat N. De la Información al Saber. Madrid: Fundesco; 1990.

11. Icart MT, Pedreny R, López R, Caja C, Girbá R, Aranda M, et al. La investigación en enfermería a través de los artículos publicados en las revistas Rol (1982-90) y Enfermería Científica (1984-90). Enfermería Científica 1991; 116:33-41.

12. Saba VK, Oatway DM, Rieder Karen A. How to use nursing information sources. Nursing Outlook 1989; 37(4):189-95. view, the current research levels must be considered a benchmark for future improvement.

As a conclusion, Spanish nursing is at the beginning of a process where the negative factors pointed out ${ }^{(24)}$ can be clearly seen. However, in the short term and in terms of the potential measures that might be taken by the Spanish government, namely a second degree and the development of doctorate studies, the situation may be improved relatively easily.

13. Price DJ de S. Hacia una Ciencia de la Ciencia. Barcelona: Ariel Quincenal; 1973

14. Maanen HMT. Nursing in transition: an analysis of the state of the art in relation to the conditions of practice and society's expectations. Journal of Advanced Nursing 1990; 15:914-24.

15. Pulpón AM, Icart MT. Análisis de las áreas prioritarias de investigación en enfermería en Cataluña (1994). Enfermería Clínica 1995; 5(4):157-62.

16. Arcas Ruiz P. Investigar en Enfermería. Prioridades y estrategias. Revista Rol de Enfermería 1990; 148:55-60.

17. Mompart García MP. Necesidades de investigación y cuidados de enfermería. Revista Rol de Enfermería 1990; 145:19-23.

18. Cabrero García J, Richart Martinez M. Análisis de la literatura empírica de la investigación enfermera española. Enfermería Científica 1992; 122:37-9.

19. Torra i Bou JE. Producción científica de la enfermería Española. Un análisis a través de los artículos publicados en tres revistas durante el trienio 1991-1993. Revista Rol de Enfermería 1995; 198:61-71.

20. Martínez Vizcaíno V, Martinez Orozco MA. Investigación en enfermería de Atención Primaria de Salud. Publicaciones de los años 1989-90. Enfermería Científica 1992; 119:18-20.

21. Puerto Fernández I González Gómez I. La investigación en oncología por parte de los enfermeros españoles en los años 199091. Enfermería Clínica 1993; 3(2):54-7.

22. Richart Martínez M, Cabrero Garcia J, Congost Mestre N, Cremades Bernabeu A, Cremades Bernabeu JA, Perez Tebar A, et al. Análisis de las referencias bibliográficas de los artículos originales publicados en tres revistas españolas de enfermería: años 1992-1993. Enfermería Clínica 1994; 4(3):118-23.

23. Tierney AJ. An analysis of nursing's performance in the 1992 assessment of research in British Universities. Journal of Advanced Nursing 1994; 19:593-602.

24. Smith LN. An analysis and reflections on the quality of nursing research in 1992. Journal of Advanced Nursing 1994; 4:319-25. 